\title{
UJI PEMANFAATAN AIR BUANGAN HATCHERY BUDIDAYA IKAN LAUT UNTUK PENDEDERAN IKAN KERAPU HIBRID CANTANG
}

\author{
Apri I Supii $^{1 *}$, Thania Inas Aprillia ${ }^{2)}$, Akhmad Adi Sulianto ${ }^{2)}$, Novia Lusiana ${ }^{2)}$ \\ ${ }^{1)}$ Balai Besar Riset Budidaya Laut, Gondol \\ 2) Program Studi Teknik Lingkungan, Jurusan Keteknikan Pertanian, FTP Universitas Brawijaya \\ *Email: aprisupii@yahoo.co.id
}

\section{ABSTRACT \\ UTILIZATION OF MARINE FISH HATCHERY WASTEWATER FOR NURSEY HIBRID GROUPER}

Buleleng Regency has the potential to develop a hybrid cantang grouper aquaculture business. However, the cultivation business in Buleleng Regency on average does not have its own waste disposal site. Ammonia is the most dangerous content of aquaculture waste for marine life. Ammonia can cause an increase and accumulation of levels of inorganic compounds that can trigger toxins for some organisms to increase the prevalence of pathogens and certain fish diseases in the waters. One treatment that can be done in reusing wastewater is to make wastewater as a place to live fish by processing using filtration and disinfection methods, namely using silica sand media, zeolite, activated charcoal, palm fiber and ultraviolet (UV). The purpose of this study is to test the feasibility of water before and after filtration, and determine the best type of water for the Cantang hybrid grouper nursery. The method used in this research is a quantitative method using RAL (Completely Randomized Design) with three treatments and four replications. After that an analysis using ANOVA is used to determine the effect of the treatment given on the parameters tested. In the study, the water quality after filtration and disinfection treatment was better than the water quality before filtration and disinfection treatment, it can be seen in the ability of the filtration and disinfection method in reducing ammonia, nitrite and total bacterial colonies by $41.30 \%, 79.75 \%$, and $76.92 \%$, and increase the water $\mathrm{pH}$ and phosphate levels to 7.50 and $27.36 \%$. In addition, the use of filtration and disinfection water can increase the survival of fish by $7.14 \%$ compared to using sea water. The survival of groupers using filtration and disinfection water is $100 \%$ while sea water is only $92.86 \%$ and wastewater is $57.14 \%$. Filtration water can reduce bacteria compared to sea water and waste water. Except for the salinity, ammonia and phosphate parameters which still do not meet the standards.

Keywords: Grouper Fish; UV Light; Water Filtration

\section{PENDAHULUAN}

\section{$1.1 \quad$ Latar Belakang}

Perairan Bali Utara dengan luas \pm $3.168 \mathrm{~km}^{2}$ yang meliputi beberapa pantai, salah satunya yaitu pantai yang berada di sepanjang Kabupaten Buleleng dengan panjang ruas pantai sekitar $144 \mathrm{~km}$. Hal ini menjadikan Kabupaten Buleleng memiliki potensi wisata pesisir dan bahari yang cukup besar, contohnya dalam pengembangan usaha budidaya berbagai komoditas laut yang memiliki prospek usaha yang menjanjikan. Tempat budidaya yang berada di Desa Penyabangan tidak memiliki tempat penampungan limbah air budidaya baik milik perorangan maupun komunal. Air buangan hasil budidaya pada umumnya dibuang langsung ke bibir pantai yang sudah 
dibuatkan saluran pembuangan yang dapat mengalirkan air buangan ke bibir pantai. Hasil pengamatan yang dilakukan pada penelitian air buangan hatchery didapatkan data bahwa air buangan budidaya perikanan yang dibuang langsung ke laut cenderung tidak bersifat toxic seperti limbah-limbah industri yang biasa dihasilkan. Walau tidak bersifat toxic ada satu material air buangan yang paling berbahaya yaitu ammonia nitrogen (Handy\&Poxton, 1993). Kadar ammonia tertentu akan menyebabkan efek stres dan toxic pada ikan, serta meningkatkan senyawa anorganik terlarut yang akan memicu eutrofikasi perairan, potensi blooming plankton, pemicu racun bagi sebagian organisme akuatik hingga meninggalkan prevelensi patogen dan penyakit ikan tertentu (Samocha et al., 2004). Hal ini dikarenakan air buangan bekas pemeliharaan ikan mengandung material organik dan anorganik yang dihasilkan dari sisa pakan, metabolisme, eksresi ikan budidaya dan residu penggunaan bahan kimia seperti pupuk, obat dan desinfektan (Zhou et al., 2015).

Salah satu treatment yang dapat dilakukan dalam pengolahan air buangan yaitu memanfaatkan kembali air buangan sebagai tempat hidup ikan dengan dilakukan pengolahan menggunakan media filter dan sinar ultraviolet (UV). Berdasarkan tahapan pengolahan limbah penambahan media filter dan sinar UV yang bertujuan untuk mengurangi konsentrasi ammonia, fosfat, nitrit dan beberapa bakteri yang berlebih pada air buangan hasil budidaya ikan merupakan tahapan pengolahan limbah tersier atau tertiary treatment. Maka dari itu penelitian ini dilakukan guna mengetahui kualitas air sebelum dan setelah proses filtrasi dengan menggunakan media filter ijuk pasir kuarsa, zeolit, arang aktif dan juga penambahan sinar UV dalam aktivitas pendederan ikan kerapu hibrid cantang. Tujuan penelitian ini adalah untuk menguji kelayakan air buangan hatchery budidaya ikan laut sebelum dan setelah dilakukan proses filtrasi dan desinfeksi dan menentukan jenis air terbaik untuk pertumbuhan budidaya ikan kerapu pada proses pendederan.

\section{METODOLOGI}

\subsection{Waktu dan Lokasi Penelitian}

Pelaksanaan penelitian dilakukan selama satu bulan yaitu dimulai pada 28 September sampai 28 Oktober 2019. Penelitian ini dilaksanakan di tempat budidaya ikan laut Apri Hatchery di Jalan Raya Seririt-Gilimanuk, Buleleng, Bali.

\subsection{Bahan dan Alat}

Bahan dasar yang digunakan pada penelitian ini yaitu air laut, air buangan dan ikan kerapu hibrid cantang yang diperoleh dari hatchery milik bapak Dr. Apri Iman Supi'I, M.Si, S.Pi. bahan lainnya yang digunakan adalah pasir kuarsa (8-16 mesh) Zeolit (0,5-1,2 mesh), Karbon aktif (4-8 mesh) dan Ijuk. Serta alat yang digunakan pada penelitian ini seperti, Lampu UV Merek Aquazonic 30 watt, kran, jaring 0.5 $\mathrm{mm}$, pompa air 125 watt, akuarium, gunting, bak filter ukuran $36 \mathrm{~cm}$ x $36 \mathrm{~cm}$ x $45 \mathrm{~cm}$, sterofoam ukuran ukuran $75 \mathrm{~cm} \mathrm{x} 42 \mathrm{~cm} \mathrm{x}$ $29 \mathrm{~cm}$, botol kaca, cool box, kamera, penyangga, sambungan pipa, timbangan digital, penggaris, thermometer, DO meter, $\mathrm{pH}$ meter dan Refraktometer.

\subsection{Pelaksanaan Penelitian}

Pelaksanaan penelitian memiliki beberapa tahapan, antara lain persiapan alat filtrasi, pengambilan sampel kualitas air, pengambilan sampel pertumbuhan ikan, pengujian sampel kualitas air, pengujian sampel pertumbuhan ikan dan analisis data.

\subsubsection{Persiapan Alat Filtrasi}

Unit filtrasi dan desinfeksi yang digunakan pada penelitian dibuat dari akuarium dengan ukuran panjang $45 \mathrm{~cm}$, lebar $36 \mathrm{~cm}$ dan tinggi $36 \mathrm{~cm}$. Kemudian akuarium dilubangi pada bagian bawah berguna sebagai saluran yang mengalirkan air hasil filtrasi menuju UV water sterillizer dengan kapasitas 30 Watt sebelum akhirnya 
dapat dimanfaatkan sebagai bahan baku perkembangan ikan kerapu hibrid cantang. Penggunaan UV water Sterillize setelah air melewati media filter disebabkan penggunaan sinar UV di awal perlakuan tidak efektif pada air keruh karena daya desinfektannya hanya dapat menembus beberapa centimeter dari permukaan air (Priano dan Satyani, 2012). Pada akuarium sebagai wadah filter dibagi menjadi lima bagian filter yaitu adalah ijuk, pasir silika, zeolit dan yang terakhir merupakan arang aktif. Pada media filter arang aktif memiliki ketebalan $12.5 \mathrm{~cm}$, ketebalan pasir silika yaitu $12.5 \mathrm{~cm}$, ketebalan zeolit yaitu $11 \mathrm{~cm}$ dan ketebalan arang aktif yaitu $9 \mathrm{~cm}$. Adapun ambar skema air dapat dilihat pada Gambar 1.

Urutan media filter

1. ljuk

2. Pasir kuarsa

3. Zeolite

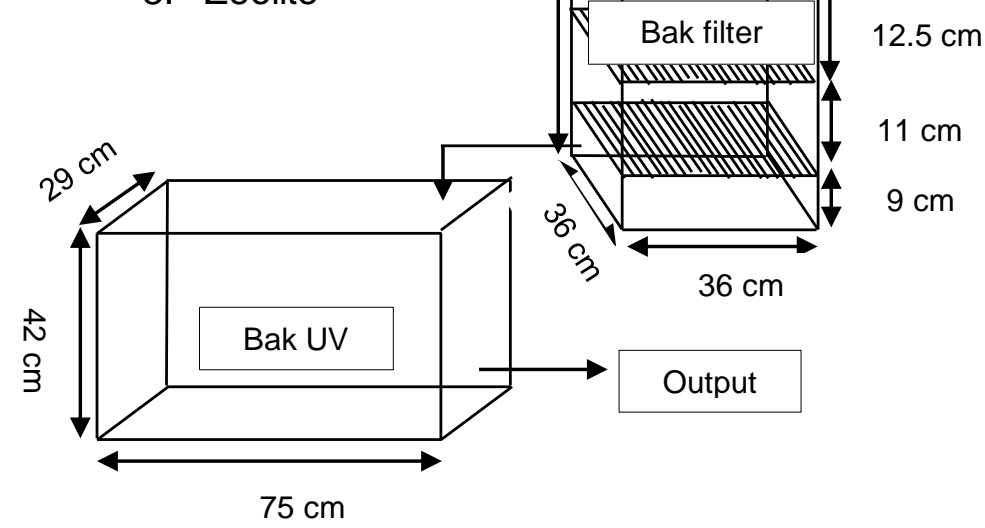

Gambar 1. Skema Air Filtrasi Dan Desinfeksi

\subsubsection{Pengambilan Sampel Kualitas Air}

\section{A. Air Buangan}

Pengambilan sampel air dengan cara mencelupkan botol dengan hati-hati ke dalam air dengan posisi mulut botol berlawanan dengan aliran air, sehingga air masuk ke dalam botol dengan tenang, kemudian isi botol sampai penuh dan hindari terjadinya turbulensi dan gelembung udara selama pengisian, setelah itu botol ditutup rapat pada saat botol masih berada di dalam air (SNI 6989.59:2008). Pengambilan sampel air buangan budidaya ikan laut sesuai yang sudah ditetapkan oleh SNI maka pengambilan sampel dilakukan pada saluran sekitar mulut pipa air.

\section{B. Air Laut}

Pengambilan sampel air laut dilakukan dengan botol uji dimasukkan ke dalam air dengan keadaan terbuka, kemudian dibilas sebanyak 3 kali, lalu diisi dengan air kemudian tutup botol tersebut sebelum dinaikkan kedaratan agar oksigen tidak masuk kedalam air tersebut. Prosedur pengambilan sampel air laut yang dilakukan pada penelitian sudah sesuai dengan Standar Nasional Indonesia. 6984.8.2015, mengenai pengambilan sampel air laut pada parameter in situ seperti suhu, $\mathrm{pH}$, salinitas, oksigen terlarut, dan lainnya.

\section{Air Filtrasi}

Pengambilan sampel air filtrasi dan desinfeksi pada akuarium ikan kerapu dilakukan dengan memasukkan botol uji pada bak penampungan yang sebelumnya sudah dibilas sebanyak tiga kali, setelah dibilas air ditampung pada botol uji dan botol uji ditutup ketika masih berada di dalam air agar tidak ada oksigen yang 
terperangkap. Pengambilan sampel air hanya dilakukan di satu titik karena aquarium yang digunakan sebagai wadah air filter dan desinfeksi berukuran kecil dengan volume air 22.464 liter dan sistem pergantian air yang digunakan adalah air mengalir sehingga dianggap homogen.

\subsubsection{Pengambilan Sampel Pertumbuhan Ikan}

Sampling dilakukan dengan cara mengambil seluruh ikan kerapu hibrid cantang ukuran dan bobot disetiap perlakuan pada empat kali pengulangan yang dilakukan pengukuran pertumbuhan ikan kerapu hibrid cantang setiap minggu baik pada bobot ikan maupun panjang ikan menggunakan milimeterblock dengan skala ketelitian $0,1 \mathrm{~cm}$ untuk mengukur panjang, sedangkan untuk pengukuran bobot ikan menggunakan timbangan digital.

\subsubsection{Pengujian Sampel Kualitas Air}

Pada penelitian dilakukan dua pengujian yaitu uji kualitas air laut, air buangan setelah dan sebelum filtrasi dan desinfeksi dan yang kedua adalah uji pertumbuhan dan kelangsungan hidup ikan kerapu hibrid cantang. Pada uji kualitas air pada 3 perlakuan yaitu air laut, air buangan dan air filtrasi menguji parameter yang sama, antara lain suhu, $\mathrm{pH}$, salinitas, oksigen terlarut, nitrit, ammonia, dan fosfat. Pada pengujian kualitas air ini dapat dilihat beberapa perubahan pada parameter yang terjadi sebelum dan sesudah air digunakan dalam proses budidaya dan setelah air difiltrasi.

\subsubsection{Pengujian Sampel Pertumbuhan Ikan}

Pada uji pertumbuhan dilakukan dengan pengukuran panjang menggunakan millimeterblok dan pengukuran bobot menggunakan timbangan analitik pada masing-masing perlakuan yang diberikan setiap satu minggu sekali terhitung dari awal ikan masuk ke bak perlakuan. Setelah didapatkan data setiap minggunya maka dilakukan perhitungan pertumbuhan panjang mutlak, pertumbuhan bobot mutlak, laju pertumbuhan dan kelangsungan hidup.

Laju pertumbuhan spesifik adalah pertumbuhan ikan dalam berat selama waktu pemeliharaan. Rumus yang digunakan pada perhitungan laju pertumbuhan spesifik menurut Effendie (2002).

$g=\frac{\operatorname{InPt}-\operatorname{InPo}}{t} \times 100 \%$

Keterangan:

$\mathrm{g}=$ Laju pertumbuhan spesifik individu (\%/hari)

$\mathrm{Pt}=$ Bobot rata-rata ikan uji pada akhir pada akhir penelitian (gram)

$\mathrm{Po}=$ Bobot rata-rata ikan uji pada awal penelitian (gram)

$\mathrm{t}$ = Lamanya penelitian (hari)

Pertumbuhan ikan dapat dibedakan menjadi dua yaitu pertumbuhan panjang mutak (PMP) dan pertumbuhan bobot multak (PMB) yang dapat dihitung menggunakan rumus Effendi et al (2006) sebagai berikut:

$$
\mathrm{L}=\mathrm{L} 2-\mathrm{L} 1
$$

Keterangan:

$\mathrm{L}=$ Pertumbuhan panjang mutlak individu (cm)

$\mathrm{L} 2=$ panjang akhir ikan $(\mathrm{cm})$

L1= Panjang awal ikan $(\mathrm{cm})$

Adapun rumus yang digunakan untuk mengukur bobot multak dapat dihitung menggunakan rumus Dewantoro (2001), sebagai berikut:

$$
\mathrm{W}=\mathrm{Wt}-\mathrm{W} 0
$$

Keterangan:

$\mathrm{W}=$ Pertumbuhan bobot mutlak individu (gram)

$\mathrm{Wt}=$ Bobot akhir ikan (gram)

$\mathrm{W} 0=$ Bobot awal ikan (gram)

Kelangsungan hidup merupakan sejumlah organisme yang hidup pada akhir pemeliharaan yang dinyatakan dalam 
persentase (Damayanti et al., 2018). Menurut Effendie (2002), pengujian yang dilakukan pada parameter ukur kelangsungan hidup (survival rate) yang diamati dengan menghitung jumlah ikan pada akhir penelitian dan dihitung berdasarkan rumus yaitu:

$\mathrm{Sr}=\frac{N t}{N o} \times 100 \%$

Keterangan:

$\mathrm{Sr}=$ Tingkat kelangsungan hidup ikan uji $(\%)$

$\mathrm{Nt}=$ Jumlah ikan uji yang hidup pada akhir penelitian (ekor)

No = Jumlah ikan uji yang hidup pada awal penelitian (ekor)

\subsection{Analisis Data}

Metode analisis data yang digunakan adalah analisis varian (ANOVA) dengan kategori Rancangan Acak Lengkap (RAL) dengan tujuan untuk mengetahui adanya pengaruh perbedaan sampel/perlakuan yang diamati. Dimisalkan terdapat $\mathrm{t}$ adalah jumlah data dan $r$ merupakan jumlah pengulangan. Sehingga terdapat tr satuan percobaan dengan hasil undian atau angka acak yang diperoleh perlakuan-perlakuan tersebut ditempatkan pada satuan percobaan tersebut (Lentner \& Bishop, 1986). Setelah dilakukan analisis menggunakan ANOVA dengan software statistical package for the social siences (SPSS) 16.0. dan didapatkan hasil akhir analisis berupa nila $F_{\text {hitung maka }}$ akan dilakukan perbandingan antara $F_{\text {hitung }}$ dengan $\mathrm{F}_{\text {tabel }}$ dengan tingakat signifikan $(\alpha=$ 0,05). Jika nilai $F_{\text {hitung }} \leq \mathrm{F}_{\text {tabel }}$ maka $\mathrm{H}_{0}$ diterima yang tidak ada pengaruh pada penelitian yang dilakukan. Akan tetapi, jika nilai $\mathrm{F}_{\text {hitung }}>\mathrm{F}_{\text {tabel }}$ maka $\mathrm{H}_{0}$ tidak di terima yang artinya pada penelitian yang dilakukan terdapat pengaruh. Jika didapatkan hasil $F_{\text {hitung }}>F_{\text {tabel }}$ yang artinya pada penelitian terdapat pengaruh maka dilanjutkan dengan uji lanjut Tukey atau BNJ (Beda Nyata Jujur) dengan tingkat signifikan $(\alpha=0,05)$.

\section{HASIL DAN PEMBAHASAN}

\subsection{Hasil Pengujian Kualitas Air}

A. Suhu

Suhu air laut (AL) sangat berpengaruh terhadap kelangsungan hidup dan pertumbuhan ikan laut, dimana perubahan suhu air laut sangat berpengaruh dalam kecepatan metabolisme tubuh dan berkaitan dengan konsentrasi oksigen terlarut (Lestari dan Dewantoro, 2018). Berdasarkan hasil pengukuran yang didapatkan, suhu air pada penelitian masih memenuhi SNI 8036.2:2014 yaitu berkisar antara $28^{0} \mathrm{C}$ $32^{\circ} \mathrm{C}$. Perbadaan suhu yang terjadi dapat disebabkan oleh proses biokimia, melalui mikroorganisme yang dapat menghasilkan panas (Patty, 2013). Berasal dari pernyataan Patty (2013) mempertegas hasil pengujian bakteri diawal penelitian yang dilakukan, bahwa pada air buangan $(\mathrm{AB})$ dan air filtrasi (AF) masih terdapat mikororganisme didalam air yang dapat menimbulkan panas. Hasil uji kualitas air sampel terhadap suhu dapat dilihat pada Gambar 2.

\section{B. Derajat Keasaman $(\mathrm{pH})$}

Derajat keasaman air laut dapat mempengaruhi pendengaran ikan yang akan mengakibatkan ikan akan sulit mendapatkan makanan sehingga dapat mempengaruhi pertumbuhan ikan kerapu (Sudjiharno dan Winanto, 1998). Pada hasil pengamatan saat dibandingkan dengan baku mutu $\mathrm{pH}$ sampel air masih memenuhi SNI 8036.2:2014 yaitu berkisar antara 7,5 sampai dengan 8,5 . Hal ini menjelaskan bahwa pada proses filtrasi yang dilakukan sudah mampu menyaring bahan organik yang dapat melakukan kegiatan fotosintesis di dalam air. Sedangkan pada air buangan ketika dilakukan pengukuran didapatkan $\mathrm{pH}$ yang masih dibawah standar baku mutu yaitu sebesar 7.49 karena disebabkan oleh pencemaran limbah yang mengandung bahan-bahan organik yang mempengaruhi pH air laut (Manik, 2003). Hasil uji kualitas air sampel terhadap $\mathrm{pH}$ air dapat dilihat pada Gambar 3. 


\section{Oksigen Terlarut}

Oksigen terlarut memiliki peranan penting terhadap pertumbuhan ikan karena oksigen terlarut dibutuhkan oleh ikan untuk bernafas, proses metabolisme atau pertukaran zat yang kemudian menghasilkan energi, energi tersebut digunakan untuk pertumbuhan dan perbiakan ikan (Salmin, 2005). Hasil pengukuran masih memenuhi SNI 8036.2:2014 yaitu minimal $4 \mathrm{mg} / \mathrm{L}$. Pada hasil pengujian yang dilakukan didapatkan hasil air buangan dan air filtrasi yang lebih rendah dibandingkan dengan air laut karena pada air buangan dan air filtrasi terdapat bakteri-bakteri anaerobik yang menggunakan oksigen dalam proses pemecahan bahan-bahan organik. Hasil uji kualitas air sampel terhadap oksigen terlarut dapat dilihat pada Gambar 4.

D. Salinitas

Salinitas air laut memiliki peranan penting terhadap perumbuhan ikan dikarenakan salinitas air akan mempengaruhi nafsu makan ikan, sehingga tingginya salinitas akan meningkatkan pertumbuhan ikan jika diimbangi dengan pemberian makan yang optimal (Septianawati dan Tjahjaningsih, 2010). Hasil pengukuran salinitas air buangan dan air filtrasi saat dibandingkan dengan baku mutu sudah melebihi standar yaitu 33 ppt. Adapun faktor yang mempengaruhi kenaikan salinitas pada air filter dan air buangan yaitu pola sirkulasi air, penguapan dan curah hujan (Patty et al, 2015). Pada air filtrasi dan air buangan di dapatkan nilai yang sama karena menurut Kalangi et al (2013), salinitas air cenderung konstan dan tidak berubah, maka dari itu pada air filtrasi yang mengunakan air buangan tidak mengalami perubahan salinitas. Hasil uji kualitas air sampel terhadap salinitas dapat dilihat pada Gambar 5.

\section{E. Bakteri Vibrio}

Berdasarkan hasil pengujian yang sudah dilakukan didapatkan hasil yang cukup baik pada data air filtrasi. Hal ini di tunjukkan pada pengujian dengan isolasi bakteri menggunakan media TSA dan
TCBS. Bakteri yang terdapat pada air laut, air filtrasi dan air buangan setelah diuji TSA dan TCBS dapat menyebabkan kelangsungan hidup ikan kerapu menurun, borok pada tubuh ikan, nafsu makan menurun, ikan kerapu cantang menjadi menghitam yang dapat menurunkan harga jual dipasaran (Desrina et al., 2006). Hal ini tentu mempengaruhi ikan kerapu cantang yang dihasilkan tidak bagus karena dan membuat kerugian bagi para pemilik usaha budidaya. Faktor yang mempengaruhi perkembangan bakteri vibrio di suatu perairan dapat disebabkan oleh $\mathrm{pH}$, aktivitas air, kemampuan mengoksidasi-reduksi, kandungan nutrient, bahan yang terkandung pada bakteri, struktur bahan makanan yang terkandung pada suatu wilayah, suhu air, oksigen terlarut, cahaya dan intensitas sinar ultraviolet (Hikmawati et al., 2019). Hasil uji kualitas air sampel terhadap bakteri vibrio dapat dilihat pada Gambar 6 .

\section{F. Ammonia}

Ammonia pada air laut mempengaruhi nafsu makan ikan, dimana semakin tinggi air laut nafsu makan ikan akan berkurang sehingga pertumbuhan ikan juga akan terhambat. Pada penelitian didapatkan kandungan ammoni di air filtrasi berkurang. Hal ini dikarenakan zeolite memiliki kemampuan menghilangkan ammonia dengan menukarkan ion natrium yang dibutuhkan oleh ikan. Hasil uji kualitas air terhadap konsentrasi ammonia. Hasil uji kualitas air sampel terhadap ammonia dapat dilihat pada Gambar 7.

\section{G. Fosfat}

Fosfat di perairan sangat berpengaruh terhadap pertumbuhan ikan karena kadungan fosfat didalam air akan mempengaruhi metabolisme pada ikan (khairuman, 2002). Pada air laut diketahui jika pengambilan air dilakukan dengan menggunakan pompa pada kedalaman kurang lebih $15-20 \mathrm{~cm}$ dari atas permukaan air laut yang cenderung kondisi perairannya lebih tenang. Maka dari itu pada pengukuran air sampel air laut kadar fosfat masih cukup kecil dibandingkan sampel air yang lainnya. 
Sedangkan tingginya kadar fosfat di air filtrasi dan air buangan ini dapat disebabkan oleh tingginya difusi fosfat dari sedimen yang berasal dari air buangan sisa budidaya (Patty et al., 2015). Hasil uji kualitas air sampel terhadap fosfat dapat dilihat pada Gambar 8.

\section{H. Nitrit}

Nitrit pada perairan mempengaruhi pertumbuhan ikan kerapu karena nitrit akan mempengaruhi kemampuan darah dalam membawa oksigen, dimana tingginya kandungan nitrit didalam air akan menghambat metabolisme pada ikan. Berdasarkan hasi pengukuran kadar nitrit pada air buangan hampir mendekati $1 \mathrm{mg} / \mathrm{L}$. Hal ini dapat dipengaruhi oleh aktivitas hatchery yang tinggi sehingga bahan organik yang di produksi pada air buangan juga meningkat. Penguraian bahan organik oleh mikrooganisme memerlukan oksigen dalam jumlah yang besar. Pada air filtrasi dengan air buangan kadar nitrit dari data penelitian menurun hingga $79.75 \%$ hal ini dipengaruhi oleh oksigen yang tersedia cukup banyak. Dengan bantuan bakteri, oksigen akan mengoksidasi nitrit menjadi nitrat dan mengakibatkan kandungan nitrit pada air sampel akan menjadi kecil (Risamasu dan Prayitno, 2011). Hasil uji kualitas air sampel terhadap nitrit dapat dilihat pada Gambar 9.

\subsection{Pengujian Pertumbuhan Ikan}

A. Pertumbuhan Bobot Mutlak

Berdasarkan hasil pengukuran yang dilakukan pada masing-masing perlakuan didapatkan jika setiap minggunya bobot ikan mengalami kenaikan yang dapat dilihat pada Gambar 10. Perbedaan pertumbuhan bobot mutlak ikan dimasing-masing perlakuan mengalami perbedaan yang dipengaruhi oleh kualitas air. Pemberian pakan ikan kerapu tergatung dengan suhu dan salinitas air, apabila suhu dan salinitas air meningkat maka nafsu makan ikan kerapu ikut meningkat. Ketika nafsu makan ikan meningkat tetapi pemberian pakan diberikan tidak sesuai maka akan menyebabkan kanibalisme Kadar nitrit yang terlalu tinggi dapat menghambat kemampuan darah dalam membawa oksigen yang akan mengakibatkan gelisah dan menghambat metabolisme ikan yang akan menyababkan kematian pada ikan (Mustafa dan Athirah, 2014). Adapun grafik perbandinga rata-rata pertumbuhan robot ikan dapat dilihat pada Gambar 10 dan hasil uji BNJ pertumbuhan bobot mutlak ikan dapat dilihat pada Tabel 1.

Tabel 1. Uji BNJ Terhadap Pertumbuhan Bobot Mutlak Ikan

\begin{tabular}{lcccc}
\hline & & \multicolumn{2}{c}{ Subset } & Notasi \\
\cline { 3 - 5 } Perlakuan & $\mathrm{N}$ & 1 & 2 & \\
\hline $\mathrm{AB}$ & 4 & 5.7200 & & $\mathrm{a}$ \\
$\mathrm{AF}$ & 4 & 6.1000 & & $\mathrm{a}$ \\
$\mathrm{AL}$ & 4 & & 8.9775 & $\mathrm{~b}$ \\
Sig. & & .881 & 1.000 & \\
\hline
\end{tabular}

\section{Sumber: Hasil Olahan Data}

Keterangan: $\mathrm{BNJ}=2.2019$

Dari hasil uji lanjut BNJ diketahui jika semikin baik kualitas airnya maka akan semakin tinggi rata-rata pertumbuhan bobot mutlak ikan. Berdasarkan hasil tersebut perlakuan menggunakan air buangan dan air filtrasi menunjukan hasil yang tidak signifikan berbeda, sehingga kedua perlakuan tersebut memiliki pertumbuhan panjang mutlak yang sama. Sedangkan pada perlakuan menggunakan air laut berbeda nyata dengan perlakuan air buangan dan air filtrasi. Hal ini disebabkan karena kualitas air laut lebih baik untuk meningkatkan bobot ikan.

\section{B. Pertumbuhan Panjang Mutlak Ikan \\ Berdasarkan hasil pertumbuhan} panjang ikan dimasing-masing perlakuan mengalami peningkatan kecuali pada penggunaan air buangan yang dapat dilihat pada Gambar 11. Perbedaan yang terjadi disebabkan oleh kualitas air yang digunakan berbeda-beda. Rendahnya $\mathrm{pH}$ air laut dapat 
mempengaruhi pendengaran ikan sehingga menyebabkan ikan sulit mendapatkan makanan dan jika dibiarkan ikan tidak akan mengalami pertumbuhan, hal ini diperkuat juga dengan tingginya kadungan ammonia pada air buangan menyababkan nafsu makan ikan berkurang (Sudjiharno dan Winanto, 1998). Selain itu, rendahnya kandungan fosfat dan tingginya kadar nitrit pada air tentu dapat menghambat kemampuan darah dalam membawa oksigen dan mempengaruhi metabolisme pada ikan, sehingga menyebabkan pertumbuhan panjang ikan kerapu di masing-masing perlakuan pada minggu pertama pengukuran mengalami perbedaan. Adapun uji $\mathrm{F}$ Terhadap pertumbuhan panjang mutlak ikan dapat dilihat pada Tabel 2 .

Tabel 2 Uji F Terhadap Pertumbuhan Panjang Mutlak Ikan

\begin{tabular}{|c|c|c|c|c|c|c|}
\hline \multicolumn{2}{|c|}{ Model } & \multirow{2}{*}{$\begin{array}{r}\text { Sum of Squares } \\
.405\end{array}$} & \multirow{2}{*}{$\frac{\mathrm{df}}{1}$} & \multirow{2}{*}{$\begin{array}{l}\begin{array}{c}\text { Mean } \\
\text { Square }\end{array} \\
.405\end{array}$} & \multirow{2}{*}{$\frac{\mathrm{F}}{3.545}$} & \multirow{2}{*}{$\begin{array}{l}\text { Sig. } \\
.089^{\mathrm{a}}\end{array}$} \\
\hline 1 & Regression & & & & & \\
\hline & Residual & 1.142 & 10 & .114 & & \\
\hline & Total & 1.547 & 11 & & & \\
\hline
\end{tabular}

Sumber: Hasil Olahan Data

Keterangan: $F_{\text {tabel }}=3.86$

Berdasarkan Tabel 2 dapat terlihat tidak adanya pengaruh antara perlakuan menggunakan air laut, air buangan dan air filtrasi terhadap pertumbuhan panjang mutlak ikan. Pada regression, $\mathrm{F}_{\text {hitung }}<\mathrm{F}_{\text {tabel }}$ $(3.545<3.86)$, sehingga dapat disimpulkan bahwa perlakuan yang diberikan tidak berpengaruh terhadap pertumbuhan panjang mutlak ikan dan tidak perlu dilakukan pengujian menggunakan BNJ (5\%).

\section{Laju Pertumbuhan}

Hasil penelitian menunjukan persentase laju pertumbuhan ikan kerapu hibrid cantang dengan menggunakan air laut, air filtrasi dan air buangan secara berurutan yaitu $5.25 \% /$ hari, $4.21 \% /$ hari dan $4.06 \% /$ hari. Perbedaan laju pertumbuhan pada masing-masing perlakuan ditentukan oleh kualitas air, pakan dan padat tebar. Kekurangan pakan akan memperlambat laju pertumbuhan dan akan menyebabkan kanibalisme pada ikan, sedangkan pemberian pakan yang secara berlebihan akan mencemari perairan yang akan menyebabkan stres pada ikan dan menjadi lemah serta nafsu makan yang akan menurun (Khairuman, 2002). Adapun kualitas air yang mempengaruhi tingginya laju pertumbuhan ikan pada air laut dibandingkan dengan air filtrasi yaitu salinitas, semakin tinggi salinitas air akan semakin tinggi nafsu makan ikan yang akan menyebabkan kanibalisme pada ikan kerapu sehingga ikan akan terluka dan akhirnya mati. selain itu kadar ammonia dapat mempengaruhi laju pertumbuhan tingginya ammonia dalam air dapat menganggu proses peningkatan oksigen oleh darah dan pada akhirnya dapat mengakibatkan sufokasi dan terjadi kematian pada ikan, Hal ini di perjelas dengan pada grafik laju pertumbuhan air laut. Adapun hasil uji bnj laju pertumbuhan ikan dapat dilihat pada Tabel 3. 
Tabel 3. Uji BNJ Laju Pertumbuhan Ikan

\begin{tabular}{lcccc} 
& \multicolumn{3}{c}{ Subset } & Notasi \\
\cline { 3 - 4 } Perlakuan & $\mathrm{N}$ & 1 & 2 & $\mathrm{a}$ \\
$\mathrm{AB}$ & 4 & 28.4475 & & \\
$\mathrm{AF}$ & 4 & 29.4725 & & $\mathrm{a}$ \\
$\mathrm{AL}$ & 4 & & 36.7300 & $\mathrm{~b}$ \\
Sig. & & & & \\
& & .886 & 1.000 &
\end{tabular}

Sumber: Olah Data

Keterangan: $\mathrm{BNJ}=6.0552$

Dari hasil uji lanjut BNJ diketahui jika semikin baik kualitas airnya maka akan semakin tinggi laju pertumbuhan ikan. Berdasarkan hasil tersebut perlakuan menggunakan air buangan dan air filtrasi menunjukan hasil yang tidak signifikan berbeda, sehingga kedua perlakuan tersebut memiliki pertumbuhan panjang mutlak yang sama. Sedangkan pada perlakuan menggunakan air laut berbeda nyata dengan perlakuan air buangan dan air filtrasi. Hal ini disebabkan karena kualitas air laut lebih baik untuk meningkatkan pertumbuhan ikan. Adapun grafik laju pertumbuhan panjang ikan dapat dilihat pada Gambar 12.

\section{Kelangsungan Hidup}

Hasil penelitian menunjukkan bahwa persentase kelangsungan hidup ikan kerapu hibrid cantang dengan menggunakan air filtrasi lebih besar dibandingkan dengan penggunaan air laut dan air buangan. Hal ini dipengaruhi oleh tingginya kematian ikan yang disebabkan oleh bakteri yang ada pada air yang digunakan. Berdasarkan data penelitian bakteri yang paling banyak terdapat pada air buangan yang dimana pada pengujian TSA didapatkan total koloni bakteri sebanyak 11 x $10^{2} \mathrm{CFU} / \mathrm{mg}$ dan untuk pengujian TCBS didapatkan total koloni bakteri sebanyak $15 \times 10^{2} \mathrm{CFU} / \mathrm{mg}$. Sedangkan, total koloni bakteri yang paling sedikit didapatkan pada penggunaan air filtrasi dengan pengujian TSA didapatkan total koloni bakteri sebanyak $5 \times 10^{0}$ $\mathrm{CFU} / \mathrm{mg}$ dan pengujian penggunakan TCBS sebayak 1 x $10^{\circ} \mathrm{CFU} / \mathrm{mg}$. Pada penggunaan air laut didapatkan total koloni bakteri pada pengujian TSA dan TCBS sebesar $7 \times 10^{0}$ $\mathrm{CFU} / \mathrm{mg}$ dan $4 \times 10^{\circ} \mathrm{CFU} / \mathrm{mg}$. Kematian ikan kerapu yang disebabkan oleh bakteri di perjelas dengan pengecekan borok pada ikan menggunakan media TSA dan TCBS sebanyak $1476 \times 10^{3} \mathrm{CFU} / \mathrm{mg}$ dan $1250 \mathrm{x}$ $10^{3} \mathrm{CFU} / \mathrm{mg}$. Bakteri-bakteri yang terdapat didalam air seperti bakteri vibrio dapat menyebabkan kerusakan pada tubuh ikan serta berubahnya nafsu makan pada ikan. Adapun hasil Uji BNJ Laju Pertumbuhan Ikan dapat dilihat pada Tabel 4.

Tabel 4. Uji BNJ Laju Pertumbuhan Ikan

\begin{tabular}{lrrrr}
\hline & \multicolumn{3}{c}{ Subset } & Notasi \\
\cline { 3 - 5 } & $\mathrm{N}$ & 1 & 2 & $\mathrm{a}$ \\
$\mathrm{AB}$ & 4 & 57.1425 & & \\
$\mathrm{AL}$ & 4 & & 92.8550 & $\mathrm{~b}$ \\
$\mathrm{AF}$ & 4 & & 100.0000 & $\mathrm{~b}$ \\
Sig. & & & & \\
& & 1.000 & .711 &
\end{tabular}

Sumber: Hasil Olahan Data

Keterangan: $\mathrm{BNJ}=35.1858$

Dari hasil uji lanjut BNJ dapat diketahui bahwa semakin sedikitnya ikan yang mati maka semakin tinggi kelangsungan hidupnya. Berdasarkan hasil uji BNJ diketahui perlakuan menggunakan air buangan berbeda nyata dengan air laut dan air filtrasi yang disebabkan karena banyaknya ikan yang mati pada air buangan. Sedangkan pada air laut dan air buangan tidak berbeda nyata karena perbandingan ikan yang mati pada air laut dengan air filtrasi hanya 2 ekor. Adapun Grafik kelansungan hidup ikan dapat dilihat pada Gambar 13. 


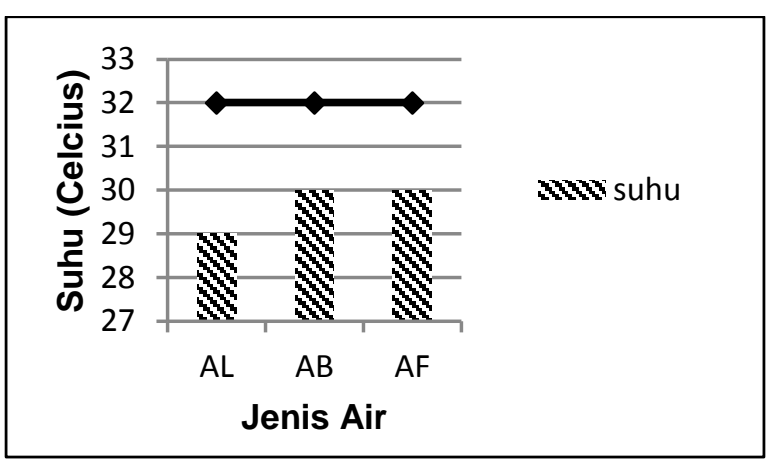

Gambar 2. Perbandingan Suhu Sampel Air Awal

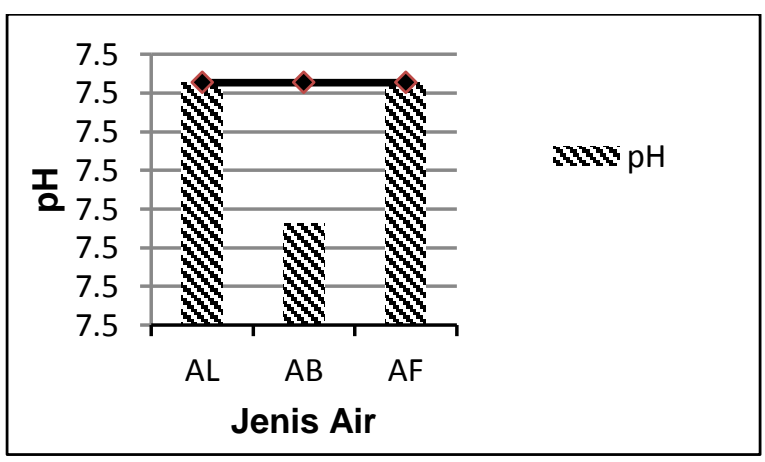

Gambar 3. Perbandingan pH Sampel Air Awal

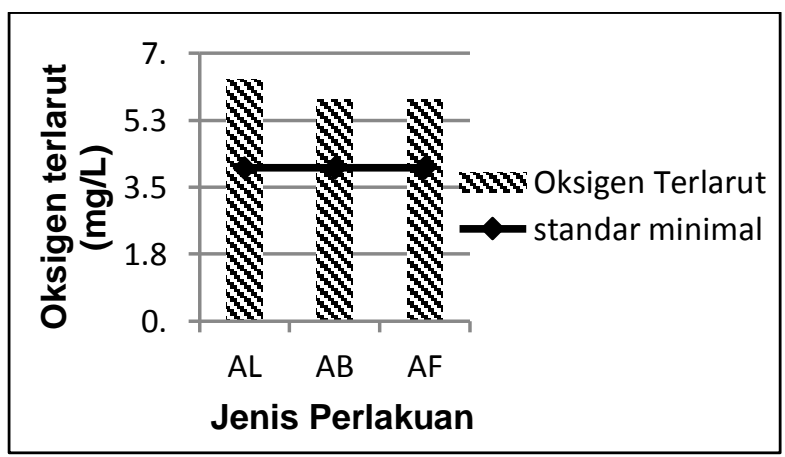

Gambar 4. Perbandingan Oksigen Terlarut Sampel Air Awal

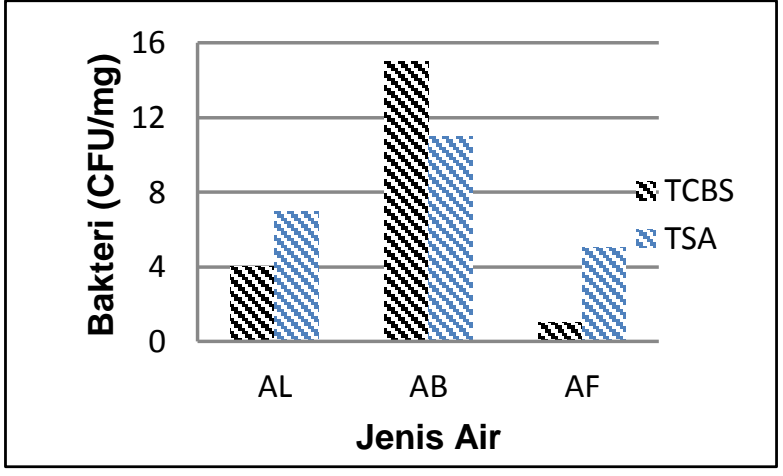

Gambar 6. Perbandingan Bakteri Sampel Air Awal

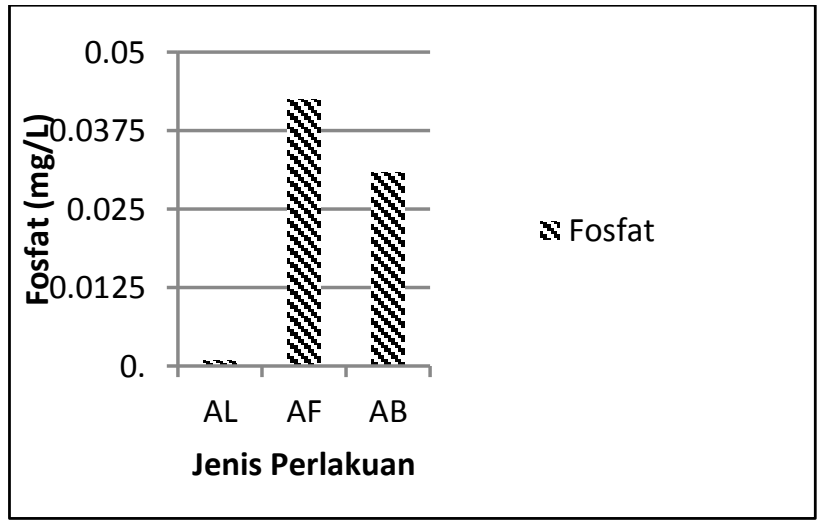

Gambar 8. Perbandingan Fosfat Sampel Air Awal

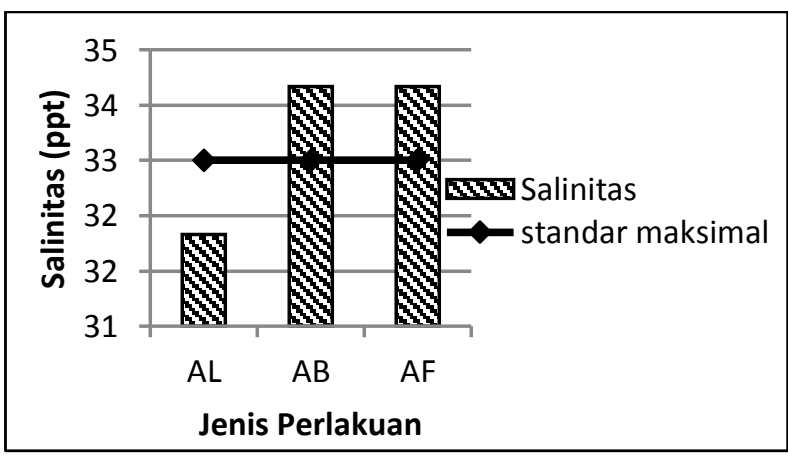

Gambar 5. Perbandingan Salinitas Sampel Air Awal 


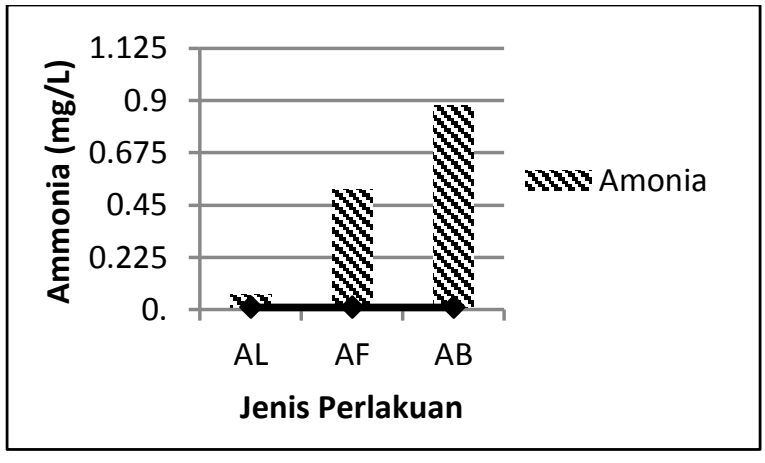

Gambar 7.Perbandingan Ammonia Sampel Air Awal

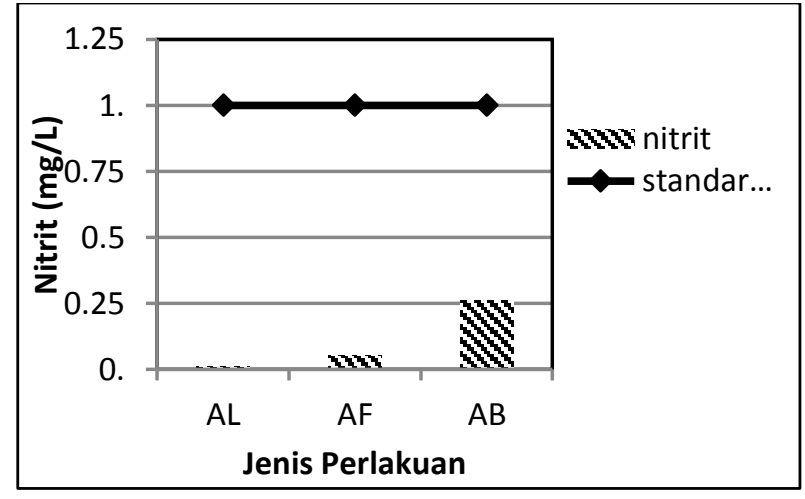

Gambar 9. Perbandingan Nitrit

Sampel Awal

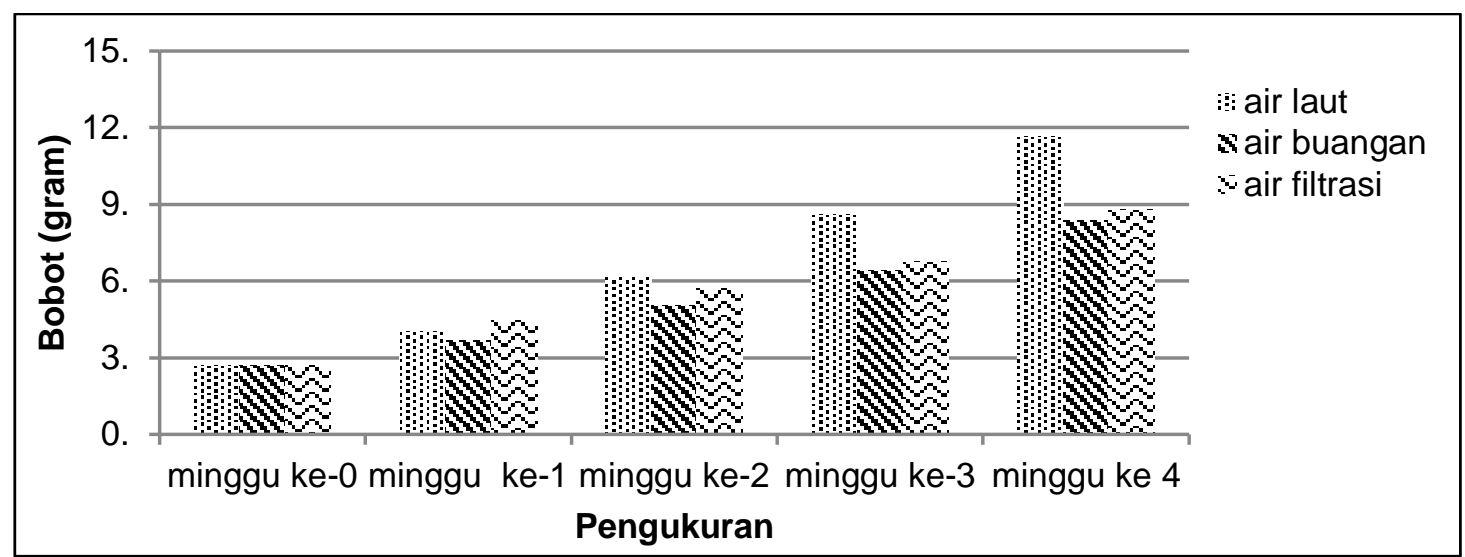

Gambar 10. Grafik Perbandingan Rata-Rata Pertumbuhan Bobot Ikan

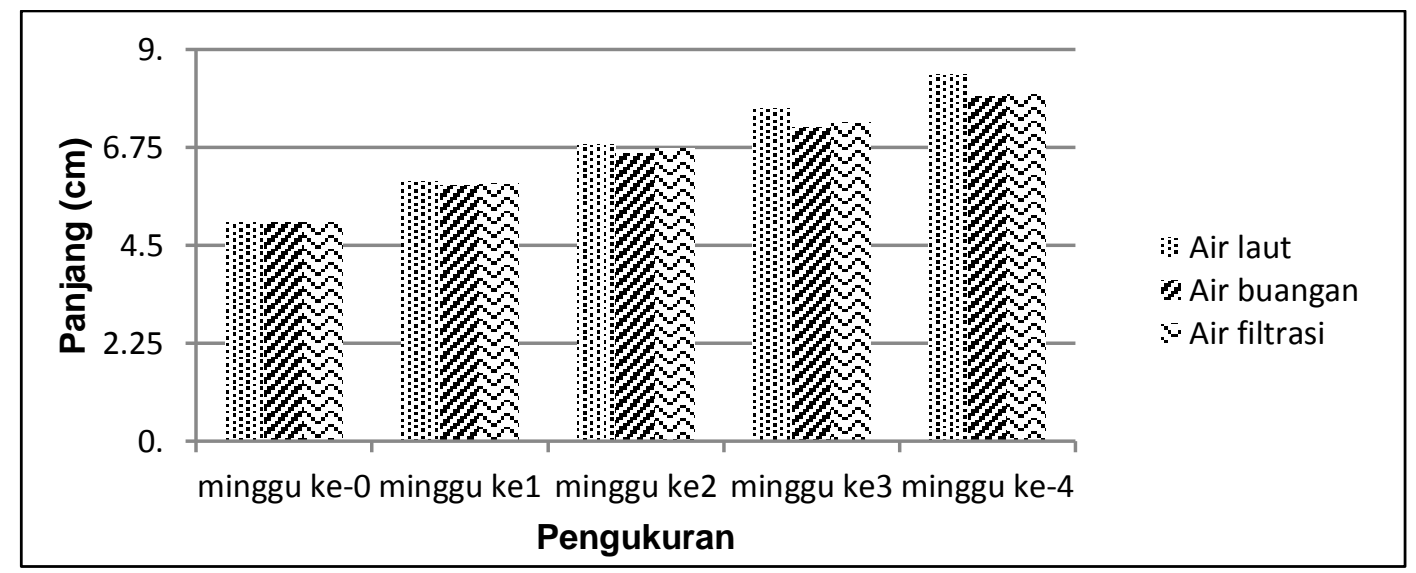

Gambar 11 Grafik Perbandingan Rata-Rata Pertumbuhan Panjang Ikan 


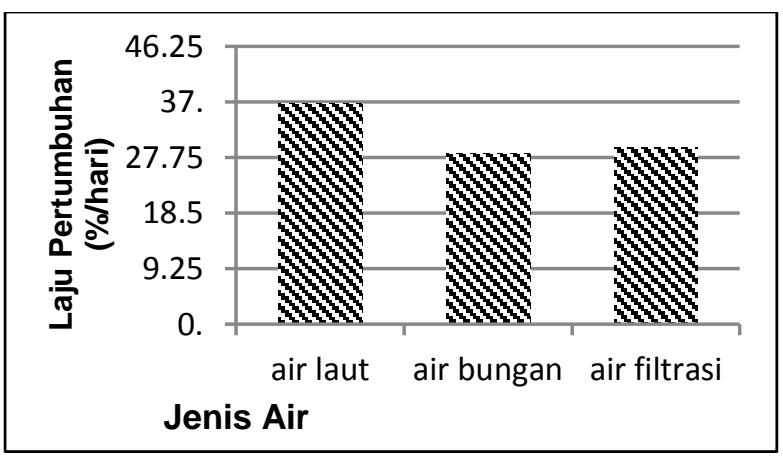

Gambar 12 Grafik Laju Pertumbuhan Panjang Ikan

\section{SIMPULAN}

1. Kualitas air setelah dilakukan perlakuan filtrasi dan desinfeksi lebih baik dibandingkan dengan kualitas air sebelum dilakukan perlakuan filtrasi dan desinfesik, dapat dilihat pada kemampuan metode filtrasi dan desinfeksi dalam menurunkan kadar ammonia sebesar $41.30 \%$, menurukan kadar nitrit sebesar $79.75 \%$, mengurangi total koloni bakteri sebanyak $76.92 \%$, miningkatkan $\mathrm{pH}$ air menjadi 7.50 dan meningkatkan kadar fosfat sebesar $27.36 \%$.

2. Air filtrasi yang dilakukan didapatkan laju pertumbuhan ikan sebesar 4.21 $\%$ /hari sedangkan pada air buangan yaitu sebesar $4.06 \%$ /haridan pada iar laut sebesar $5.25 \% /$ hari. Selain itu kelangsungan hidup ikan kerapu menggunakan air filtrasi sebesar 100\% sedangkan air laut hanya sebesar $92.86 \%$ dan air buangan sebesar $57.14 \%$. Pada penelitian yang dilakukan didapatkan hasil bahwa filter mampu mereduksi bakteri dibandingkan dengan air laut dan air buangan. Kecuali untuk parameter salinitas, ammonia dan fosfat yang masih belum memenuhi standar.

3. Penggunaan air filter dan desinfektan pada proses pendederan ikan kerapu cantang hanya berpengaruh terhadap pertumbuhan bobot mutlak ikan, laju

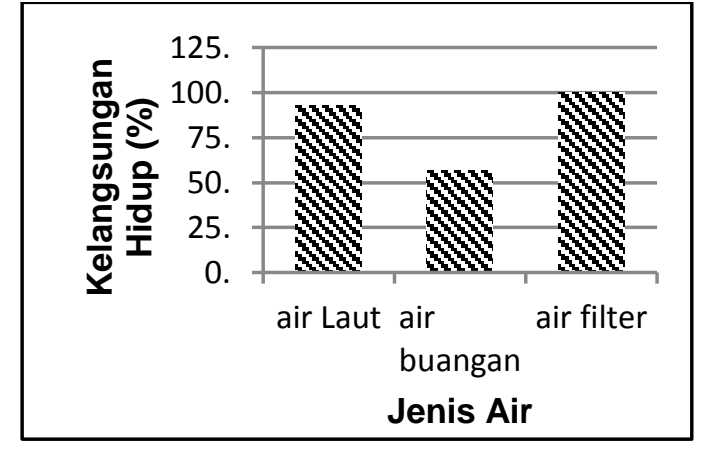

Gambar 13 Grafik Kelangsungan Hidup Ikan Pada Masing-masing Perlakuan

pertumbuhan ikan dan kelangsungan hidup ikan. Namun penggunaan air filter dan desinfektan tidak berpengaruh terhadap pertumbuhan panjang mutlak ikan kerapu hibrid cantang dalam proses pendederan.

\section{DAFTAR PUSTAKA}

Damayanti., Eka indah Raharjo dan Farida. 2018. Sistem Resirkulasi Menggunakan Kombinasi Filtrasi Yang Berbeda Terhadap Pertumbuhan Benih Ikan Jelawat (Leptobarbus Hoeveni). Jurnal Ruaya. Vol. 6, No.2:1-8.

Desrina., Arief Taslihan., Ambariyanto dan Susiani suryaningrum. 2006. Uji Keganasan Bakteri Vibrio Pada Ikan Kerapu Macan (Epinephelus Fuscoguttatus). Ilmu Kelautan. Volume. 11(3):119-125.

Dewantoro, G.W. 2001. Fekunditas Dan Produksi Larva Pada Ikan Cupang (Berra Splendens Regan) Yang Berbeda Umur Dan Pakan Alaminya. Fakultas Biologi, Universitas Nasional Jakarta. Jurnal Iktiologi Indonesia, 1(2):49-52.

Effendie MI. 2002. Biologi perikanan. Yayasan Pustaka Nusatama, Yogyakarta..

Effendi, I., N.J. Bugri dan Widanarmi. 2006. Pengaruh Pada Penebaran 
Terhadap Pertumbuhan Benih Ikan Gurami Osphronemus Gouramy Ukuran 2 cm. Jurnal Akuakultur Indonesia , 5 (2): 127-135.

Handy, R. D dan Poxton, M.G. 1993. Nitrigen pollution In mariculture: Toxicity And Excretion Of Nitrogenous Compounds By Marine Fish. Rev. Fish Biol. Fish. 205-241.

Hikmawati, Farida., Ari Susilowati dan Ratna Setyaningsih. 2019. Deteksi Jumlah dan Uji Patogenitas Vibrio spp. Pada Kerang Hijau (Perna viridis) Dikawasan Wisata Pantai Yogyakarta. PROS SEM NAS MASY BIODIF INDOV: volume 5, Nomor 2(334-339)

Kalangi, Patrice NI., Aselum Mandagi., KWA Masengi., Alfert Luasunaunh., FTP Pangalila dan Masamitsu Iwata. 2013. Sebaran Suhu Dan Salinitas Di Teluk Manado.Jurnal Perikanan dan Kelautan Tropis IX(2):71-75

Khairuman. 2002. Budidaya Patin Super. Agromedia Pustaka. Jakarta

Lestari, Tuti Puji dan Eko Dewantoro. 2018. Pengaruh Suhu Media Pemeliharaan Terhadap Laju Pemangsaan dan Pertumbuhan Larva Ikan Lele Dumbo (Clarias Gariepinus). Jurnal Ruaya Vol.6. No.1.

Manik, K.E.S. 2003. Pengelolaan Lingkungan Hidup. Djambatan Jakarta.

Patty, Simon I. 2013. Distribusi Suhu, Salinitas Dan Oksigen Terlarut Di Perairan Kema,Sulawesi Utara. Jurnal Ilmiah Platax. Vol. 1(3).

Patty, Simon I., Hairat Arfah dan Malik S. Abdul. 2015. Zat Hara (Fosfat, Nitrat), Oksigen Terlarut Dan $p H$ Kaitannya Dengan Kesuburan Di Perairan Jikumersa, Pulau Buru. Jurnal Pesisir dan Laut Tropis. Volume 1, Nomor 1(43-50).
Risamasu, Fonny J.L dan Hanif Budi Prayitno. 2011. Kajian Zat Hara Fosfat, Nitrit, Nitrat Dan Silikat Di Perairan Kepualauan Matasiri, Kalimantan Selatan. Ilmu Kelautan. Vol. 16(3): 135-142.

Salmin. 2005. Oksigen Terlarut (DO) Dan Kebutuhan Oksigen Biologi (BOD) Sebagai Salah Satu Indikator Untuk Menentukan Kualitas Perairan. Oseana, Volume 30,Nomor 3: 21-26

Samocha, T.M., Lopez, I.M., Jones, E.R., Jackson, S dan Lawrence, A.L.2004. Characterization of Intake And Effluent Water From Intensive And Semiuntensive Shrimp Farms In Texas. Aquaculture Research, 35, 321339.

Septianawati., Atmira dan Wahyu Tjahjaningsih.2010. Manajemen pembesaran Kerapu Tikus (cromileptes altivesis) Di Balai Besar Pengembangan Budidaya Air Payau (BBPBAP) Jepara Jawa Timur. Jurnal Ilmiah Perikanan dan Kelautan Vol, 2, No.1.

Sudjiharno dan Winanto, $\mathrm{T}$. 1998.Pembenihan Kerapu Macan (Ephinephelus Fuscoguuatus).

Dapartemen Pertanian Direktorat Jendral Perikanan Balai Budidaya Laut Lampung. 16-17 hal.

Standar Nasional Inodnesia (SNI) 6989.59:2008. Metode Pengambilan Contoh Air Limbah. Badan Standarisasi Nasional.

Zhou, L., Boyd C., Brady, Y., Chappel, J dan $\mathrm{Li}, \mathrm{X}$. (2015). Investigation Of Ammonia Niyrogen In Aquaculture: The Methodology, Concentrations, Removal And Pond Fertilization. Dissertation Of Graduate Faculty Of Auburn University. Alabama, USA, 116 pp. 